\title{
Analiza stanu gleb w raportach o oddziaływaniu na środowisko wybranych obiektów gospodarki odpadami
}

\begin{abstract}
Streszczenie: Gleba jest jednym z elementów środowiska przyrodniczego, który często bywa narażony na zanieczyszczenia i degradację. Jednym z głównych źródeł zanieczyszczeń są obiekty gospodarki odpadami, wśród których dominują składowiska odpadów. W Polsce obiekty gospodarki odpadami są zaliczane do przedsięwzięć mogących potencjalnie znacząco oddziaływać na środowisko. Dla większości takich obiektów przeprowadzana jest ocena oddziaływania na środowisko, w ramach której sporządzany jest raport o oddziaływaniu na środowisko. Problematyka ochrony gleb jest jednak często w nim marginalizowana. Celem pracy była analiza jakości wybranych raportów o oddziaływaniu na środowisko obiektów gospodarki odpadami, ze szczególnym uwzględnieniem przeprowadzonej w nich analizy stanu gleb, a także przedstawienie propozycji zakresu prac, niezbędnych do rzetelnej analizy oddziaływania obiektów gospodarki odpadami na gleby. Wyniki przeprowadzonej oceny wskazują na zróżnicowany poziom wykonania w zakresie przedstawienia oddziaływania inwestycji na gleby. Przeważają opracowania ocenione negatywnie jako niezadowalające.
\end{abstract}

Stowa kluczowe: gleba, ocena oddziaływania na środowisko, oddziaływanie na gleby

\section{WSTĘP}

Gleba jest jednym z najważniejszych komponentów naturalnych ekosystemów ladowych! - to myśl, która przyświecać będzie obchodom Międzynarodowego Roku Gleby (2015).

Gleba jest jednym z elementów środowiska przyrodniczego, który często bywa narażony na zanieczyszczenia i degradację przez akumulowanie w niej pierwiastków i związków chemicznych, które przedostają się do niej w skutek działalności człowieka (Kabata-Pendias i Pendias 1999). Jednym z głównych źródeł metali ciężkich są obiekty gospodarki odpadami, wśród których dominują składowiska odpadów. W strumieniu odpadów komunalnych wstępuje bowiem od 3,7 do 7\% tych metali (Szyszkowski i in. 2000).

W wielu pozycjach literaturowych można spotkać ocenę wpływu obiektów gospodarki odpadami, w szczególności składowisk odpadów na właściwości gleb. Wielu autorów zwraca uwagę na podwyższoną zawartość metali ciężkich w glebach znajdujących się w zasięgu ich oddziaływania (Kondras i in. 2010). Niektórzy uważają, że pomimo prawidłowego przygotowania i eksploatacji takich obiektów, otaczające środowisko jest zagrożone (Jędrczak i Drab 1989). Można także spotkać opinie, że pomimo długotrwałej eksploatacji składowiska nie wywiera ono istotnego wpływu na zawartość metali ciężkich w glebach (Świercz 2005, Niedźwiecki i in. 2008), jak i na stan zanieczyszczenia gleb (Bojarska i Bzowski 2009).

Istotnym aspektem oddziaływania obiektów gospodarki odpadami na gleby jest emisja zanieczyszczeń mikrobiologicznych (bioaerozoli). Wśród różnych komponentów środowiska przyrodniczego gleba zajmuje bardzo ważne miejsce ze względu na to, że jest ośrodkiem gromadzenia się różnych zanieczyszczeń, w tym także zanieczyszczeń mikrobiologicznych, pochodzących np. z odpadów komunalnych (Barabasz i in. 2007; Frączek 2010). Największa liczebność mikroflory gleby występuje w najbliższym sąsiedztwie składowiska odpadów, zwłaszcza w powierzchniowej warstwie gleby (Przybulewska i in. 2010).

Problemy dotyczące gospodarki odpadami i ograniczenia ich negatywnego oddziaływania na środowisko zaliczane są do jednych z najważniejszych zagadnień ochrony środowiska. Polska jest bowiem zobowiązana do ponownego zagospodarowania jak największej ilości odpadów i ograniczenia ich ilości deponowanych na składowiskach. Pociaga to za soba konieczność budowy kompleksowych obiektów unieszkodliwiania odpadów komunalnych, w obrębie których powinny się znaleźć m.in. sortownie, kompostownie, instalacje do produkcji paliw alternatyw- 
nych i termicznego ich wykorzystania oraz składowisko odpadów.

Zgodnie z rozporządzeniem Rady Ministrów z dnia 9 listopada 2010 r. w sprawie przedsięwzięć mogących znacząco oddziaływać na środowisko (Dz.U. 2010, nr 213, poz. 1397, z późn. zm.) obiekty gospodarki odpadami komunalnymi są zaliczane do przedsięwzięć mogących potencjalnie znacząco oddziaływać na środowisko. Dla większości takich obiektów przeprowadzana jest ocena oddziaływania na środowisko, w ramach której sporządzany jest raport o oddziaływaniu na środowisko (raport ooś). W myśl ustawy z dnia 3 października 2008 r. o udostępnianiu informacji o środowisku i jego ochronie, udziale społeczeństwa w ochronie środowiska oraz o ocenach oddziaływania na środowisko (tekst jedn.: Dz.U. 2013, poz. 1235, z późn. zm.) raport o oddziaływaniu na środowisko powinien przedstawiać stan środowiska w rejonie planowanej inwestycji i analizę wpływu inwestycji na środowisko, w tym na gleby. Problematyka ochrony gleb jest jednak często marginalizowana $w$ takich opracowaniach.

Celem pracy była analiza wybranych raportów o oddziaływaniu na środowisko obiektów gospodarki odpadami, ze szczególnym uwzględnieniem przeprowadzonej w nich analizy stanu gleb, niezbędnej do prawidłowego określenia wpływu planowanej inwestycji na ten komponent środowiska. Celem pracy było także przedstawienie propozycji zakresu prac niezbędnych do rzetelnej analizy oddziaływania obiektów gospodarki odpadami na gleby.

\section{MATERIAŁ I METODY}

Analizie poddano wybrane raporty o oddziaływaniu na środowisko planowanych zakładów zagospodarowania odpadów pod względem szczegółowości przeprowadzonej w nich oceny wpływu inwestycji na gleby:

Z1 - Zakład Zagospodarowania Odpadów w Bełżycach, powiat lubelski, województwo lubelskie,

Z2 - Zakład Zagospodarowania Odpadów Jarocin, powiat jarociński, województwo wielkopolskie,

Z3 - Zakład Zagospodarowania Odpadów w Kopaszynie Nowe, powiat trzebnicki, województwo wielkopolskie,

Z4 - Zakład Zagospodarowania Odpadów w Siemiatyczach, powiat siemiatycki, województwo podlaskie,

Z5 - Zakład unieszkodliwiania i odzysku odpadów w gminie Skarbimierz, powiat brzeski, województwo opolskie,

Z6 - Zakład Unieszkodliwiania Odpadów „Ekolina" w gminie Zielonka, powiat wołomiński, województwo mazowieckie.
Oceny szczegółowości przeprowadzonych w raportach ooś analiz wpływu inwestycji na gleby dokonano metodą listy kontrolnej bez szacowania. Proces oceny składał się z następujących elementów:

a) opracowanie listy kontrolnej kryteriów ocen cząst-

kowych:

- elementów z zakresu raportu o oddziaływaniu na środowisko określonego $\mathrm{w}$ art. 66 ust. 1 ustawy z dnia 3 października 2008 r. o udostępnianiu informacji o środowisku i jego ochronie, udziale społeczeństwa w ochronie środowiska oraz o ocenach oddziaływania na środowisko,

- wyników badań gleb i środowiska gruntowowodnego wykorzystanych $w$ ramach oceny stanu środowiska i jego zagrożeń ze strony planowanej inwestycji,

b) analiza poszczególnych kryteriów ocen cząstkowych sześciu raportów o oddziaływaniu na środowisko opracowanych w latach 2008-2011,

c) podsumowanie i analiza wyników oceny.

\section{WYNIKI I DYSKUSJA}

\section{Analiza wybranych raportów o oddziaływaniu na środowisko}

Celem opracowywania raportów o oddziaływaniu na środowisko jest scharakteryzowanie oraz oszacowanie wpływu planowanej inwestycji na środowisko. Dużym problemem jest jednak prawidłowa analiza różnorodnych danych związanych z wpływem planowanego przedsięwzięcia na wszystkie komponenty środowiska, w tym na glebę.

Analizując aktualny stan gleb oraz wpływ planowanej inwestycji na ten komponent środowiska należy rozważyć wszystkie potencjalne zagrożenia. Opierając się na dostępnych wynikach badań lub też na wynikach uzyskanych na drodze przeprowadzonych analiz dla potrzeb opracowania raportu oddziaływania na środowisko, można ocenić podatność danej gleby na akumulację lub migrację różnych substancji zanieczyszczających. Podatność gleb jest cechą ściśle uwarunkowaną właściwościami fizykochemicznymi (m.in. uziarnieniem, odczynem, zawartością i jakością materii organicznej lub pojemnością kompleksu sorpcyjnego gleby). Bez ich znajomości trudno jest ocenić wpływ planowanego przedsięwzięcia na ten komponent środowiska. Szczególnie, jeśli planowana inwestycja spowoduje zmianę użytkowania terenu, co ma miejsce w przypadku budowy składowisk odpadów czy zakładów zagospodarowania odpadów. Na ten problem zwracał także uwagę Gruszczyński (2006). 
Zakres raportu o oddziaływaniu na środowisko jest określony w ustawie $\mathrm{z}$ dnia 3 października $2008 \mathrm{r}$. o udostępnianiu informacji o środowisku i jego ochronie, udziale społeczeństwa w ochronie środowiska oraz o ocenach oddziaływania na środowisko. Zgodnie z art. $66 \mathrm{ww}$. ustawy raport o oddziaływaniu przedsięwzięcia powinien zawierać m.in.:

- opis przyrodniczych elementów środowiska w na terenie przeznaczonym pod inwestycję $\mathrm{i} w$ zasięgu jej oddziaływania,

- analizę oddziaływania planowanego przedsięwzięcia na środowisko,

- określenie działań mające na celu ograniczenie oddziaływania przedsięwzięcia na środowisko,

- zalecenie monitoringu środowiska,

- wnioski.

Jednym z elementów środowiska, na który oddziaływanie planowanego przedsięwzięcia powinno zostać przeanalizowane, są gleby.

Wszystkie analizowane raporty zostały sporządzone w pełnym zakresie w oparciu o zapisy ww. ustawy. Jednak w większości z nich charakterystyka gleb $\mathrm{i}$ ich stanu, a także opis oddziaływania inwestycji na ten element środowiska zostały potraktowane bardzo ogólnie. Wyniki przeprowadzonej oceny wskazują za zróżnicowaną jakość i dokładność prezentowanych zagadnień związanych z oddziaływaniem inwestycji na gleby (tab. 1). Potwierdzają jednocześnie marginalizowanie kwestii oddziaływania inwestycji na gleby oraz możliwości akumulowania i migracji w glebach zanieczyszczeń.

Spośród sześciu przeanalizowanych raportów, w czterech przypadkach planowane inwestycje związane były z rozbudową istniejącego obiektu gospodarki odpadami (Z1, Z2, Z3 oraz Z4) przez budowę w sąsiedztwie istniejącego składowiska odpadów obiektów takich, jak: sortownia odpadów, kompostownia lub stacja demontażu pojazdów. Dwa pozostałe dotyczyły przedsięwzięcia inwestycyjnego polegającego na budowie zakładu unieszkodliwiania i odzysku odpadów na terenie dawnego lotniska wojskowego (Z5) oraz na budowie takiego obiektu na terenie nieczynnego składowiska odpadów paleniskowych, pochodzących z elektrociepłowni (Z6). Wszystkie obiekty planowane były zatem na terenach, na których gleby mogły w przeszłości zostać zanieczyszczone zarówno metalami ciężkimi, jak i produktami ropopochodnymi.

Tylko w jednym przypadku w raporcie oddziaływania na środowisko związanego z planowaną budową Zakładu Unieszkodliwiania Odpadów „Ekolina" w gminie Zielonka (Z6) dokonano opisu wykorzystanych metod analizy oddziaływania na po- wierzchnię ziemi i gleby. W pozostałych opracowaniach takiego rozdziału nie było i nie przedstawiono metod pracy, także w rozdziałach poświęconych oddziaływaniu inwestycji na środowisko.

Składowiska odpadów są obiektami, w przypadku których istnieje obowiązek prowadzenia monitoringu. Zakres obowiązkowych badań monitoringowych określa rozporządzenie Ministra Środowiska z dnia 9 grudnia 2002 r. w sprawie zakresu, czasu, sposobu oraz warunków prowadzenia monitoringu składowisk odpadów (Dz.U. 2002, nr 220, poz 1858). W związku ze specyfiką planowanych inwestycji, w większości polegających na rozbudowie istniejących obiektów, zastanawiające było wykorzystanie wyników badań prowadzonego monitoringu wybranych elementów środowiska, w tym gleb lub wyników jednorazowych badań przeprowadzonych na danym terenie $\mathrm{w}$ przeszłości. Zaobserwowano bardzo zróżnicowane podejście do rozpoznania istniejącego stanu gleb w rejonie planowanej inwestycji. Najczęściej autorzy raportów wspominają o prowadzonym monitoringu, głównie wód, natomiast nie odnoszą się do wyników monitoringu innych elementów środowiska, w tym gleb. Nie podają też wyników monitoringu i nie analizują ich w odniesieniu do obowiązujących standardów jakości środowiska.

Autorzy raportów w większości przypadków wspominają o jednorazowych, wykonywanych na terenie inwestycji badaniach, głównie geologicznoinżynierskich, rzadziej hydrogeologicznych, jeszcze rzadziej oceniających jakość wód, gleb i ziemi. Omawiają na ich podstawie budowę geologiczną i warunki hydrogeologiczne, najczęściej bardzo ogólnie, bez odnoszenia się do wyników jakości środowiska gruntowo-wodnego.

Typowym przykładem jest raport dla inwestycji Z5, która polega na budowie nowej instalacji do unieszkodliwiania i odzysku odpadów na terenie dawnego lotniska wojskowego, wykorzystywanego do 1993 r. przez wojska radzieckie. Jak w większości tego typu obiektów gleby i wody gruntowe na terenie lotniska i w jego rejonie były zanieczyszczone substancjami ropopochodnymi i metalami ciężkimi (Gurwin i Janczarski 1998; Kaszubkiewicz i in. 1998). W analizowanym raporcie nie odniesiono się do wyników badań jakości wód, gleb i ziemi, które zostały przeprowadzone dla terenu byłego lotniska i których wyniki zostały omówione zarówno w dokumentacjach oraz raportach, jak i w publikowanych artykułach.

Wyjątek stanowi opracowanie dotyczące Zakładu Unieszkodliwiania Odpadów „Ekolina” w gminie Zielonka (Z6), w którym szczegółowo omówiono stan gleb na podstawie archiwalnych badań z 1991 i 2006 roku Przeanalizowano zawartości metali ciężkich 
TABELA 1. Lista kontrolna oceny szczegółowości przeprowadzonych analiz wpływu inwestycji na gleby w raportach o oddziaływaniu na środowisko obiektów gospodarki odpadami

TABLE 1. Checklist for the accuracy assessment of soil condition analyses performed within the framework of EIA raports for waste management facilities

\begin{tabular}{|c|c|c|c|c|c|c|c|}
\hline $\begin{array}{l}\text { Lp. } \\
\text { No }\end{array}$ & $\begin{array}{l}\text { Kryteria oceny } \\
\text { Evaluation criteria }\end{array}$ & $\mathrm{Z} 1$ & $\mathrm{Z} 2$ & $\mathrm{Z3}$ & Z4 & Z5 & Z6 \\
\hline 1 & 2 & 3 & 4 & 5 & 6 & 7 & 8 \\
\hline 1. & $\begin{array}{l}\text { Budowa nowego zakładu/ rozbudowa } \\
\text { istniejacego obiektu } \\
\text { Construction of a new facility / extending } \\
\text { existing facility }\end{array}$ & $\begin{array}{l}\mathrm{R} \\
\text { (przy } \\
\text { istniejącym } \\
\text { składowisku } \\
\text { odpadów) }\end{array}$ & $\begin{array}{l}\text { R } \\
\text { (przy } \\
\text { istniejącym } \\
\text { składowis- } \\
\text { ku } \\
\text { odpadów) }\end{array}$ & $\begin{array}{l}\text { B } \\
\text { (przy } \\
\text { istniejacym } \\
\text { składowis- } \\
\text { ku } \\
\text { odpadów) }\end{array}$ & $\begin{array}{l}\text { R } \\
\text { (przy } \\
\text { istniejacym } \\
\text { składowisku } \\
\text { odpadów) }\end{array}$ & $\begin{array}{l}\text { R } \\
\text { (na terenie } \\
\text { dawnego } \\
\text { lotniska) }\end{array}$ & $\begin{array}{l}\text { B } \\
\text { (na terenie nie- } \\
\text { czynnego skła- } \\
\text { dowiska odpadóv } \\
\text { paleniskowych } \\
\text { EC Żerań) }\end{array}$ \\
\hline
\end{tabular}

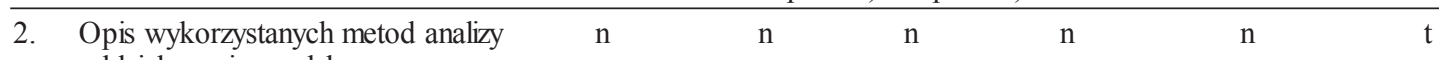

oddziaływania na gleby

Description of the methods of analysis

of the impact of soil

3. Badania środowiska gruntowo-wodnego $\mathrm{t} / \mathrm{t}(\mathrm{gi}, \mathrm{h}) \mathrm{t} / \mathrm{t}(\mathrm{h}, \mathrm{gi}) \mathrm{t} / \mathrm{n} \quad \mathrm{t} / \mathrm{t}(\mathrm{gi}) \quad \mathrm{t} / \mathrm{t}$ (gi) $\mathrm{t} / \mathrm{t}$ (gi, h, ssg-w) w rejonie inwestycji / wykorzystanie ich wyników

Research of soil and water in the area of investment / exploitation of the results

4. Monitoring środowiska w rejonie $\mathrm{t} / \mathrm{n} \quad \mathrm{t} / \mathrm{t} \quad \mathrm{t} / \mathrm{n} \quad \mathrm{t} / \mathrm{n} \quad \mathrm{n} /-\mathrm{n} /-$ inwestycji / wykorzystanie wyników Environmental monitoring in the area of investment / use of results

5. Badania gleb dla potrzeb raportu ooś Research of soil for EIA raport

6. Uwzględnienie w charakterystyce gleb:

Taking into account the characteristics of the soil:

\begin{tabular}{lllllll}
\hline $\begin{array}{l}\text { typów } \\
\text { types }\end{array}$ & $\mathrm{n}$ & $\mathrm{n}$ & $\mathrm{n}$ & $\mathrm{n}$ & $\mathrm{n}$ & $\mathrm{t}$ \\
\hline $\begin{array}{l}\text { klas bonitacyjnych } \\
\text { the grading class }\end{array}$ & $\mathrm{n}$ & $\mathrm{n}$ & $\mathrm{n}$ & $\mathrm{t}$ & $\mathrm{n}$ & $\mathrm{t}$ \\
\hline $\begin{array}{l}\text { rodzaju i gatunku } \\
\text { type and species }\end{array}$ & $\mathrm{n}$ & $\mathrm{n}$ & $\mathrm{n}$ & $\mathrm{n}$ & $\mathrm{n}$ & $\mathrm{t}$ \\
\hline $\begin{array}{l}\text { użytkowania w rejonie inwestycji } \\
\text { using the area of investment }\end{array}$ & $\mathrm{n}$ & $\mathrm{t}$ & $\mathrm{n}$ & $\mathrm{t}$ & $\mathrm{t}$ & $\mathrm{t}$ \\
$\begin{array}{l}\text { analiza oddziaływania na gleby na etapie } \\
\text { budowy inwestycji } \\
\begin{array}{l}\text { assessment of soil condition analyses } \\
\text { during construction investment: }\end{array}\end{array}$ & $\mathrm{n}$ & $\mathrm{t}$ (ogólnie) & $\mathrm{t}$ (ogólnie) & $\mathrm{t}$ (ogólnie) & $\mathrm{t}$ (ogólnie) & $\mathrm{t}$ \\
\hline
\end{tabular}

7. Analiza oddziaływania gleby na etapie eksploatacji inwestycji:

Assessment of soil condition analyses during life of the investment:

\begin{tabular}{|c|c|c|c|c|c|c|}
\hline $\begin{array}{l}\text { - emisja pyłu } \\
\text { dust emission }\end{array}$ & $\mathrm{t}$ & $\mathrm{t}$ & $\mathrm{t}$ & $\mathrm{t}$ & $t$ & $\mathrm{t}$ \\
\hline $\begin{array}{l}\text { - emisja bioaerozoli } \\
\text { bioaerosol emissions }\end{array}$ & $\mathrm{n}$ & $\mathrm{n}$ & $\mathrm{n}$ & $\mathrm{n}$ & $\mathrm{r}$ & $\mathrm{t}$ \\
\hline $\begin{array}{l}\text { - emisja zanieczyszczeń w spływach } \\
\text { opadowych i odciekach } \\
\text { emissions in the run-off rainwater } \\
\text { and leachate }\end{array}$ & $\mathrm{n}$ & $\mathrm{t}$ & $\mathrm{t}$ & $\mathrm{t}$ & $\mathrm{t}$ & $\mathrm{t}$ \\
\hline $\begin{array}{l}\text { Przedstawienie działań ochronnych } \\
\text { Presentation of protective measures }\end{array}$ & $\mathrm{n}$ & $\mathrm{t}$ & $\mathrm{t}$ & $\begin{array}{l}\mathrm{t} \\
\text { (o } \\
\text { ro } \\
\text { oc }\end{array}$ & $t$ & $\mathrm{t}$ \\
\hline
\end{tabular}


cd. tabeli 1

\begin{tabular}{|c|c|c|c|c|c|c|c|}
\hline 1 & 2 & 3 & 4 & 5 & 6 & 7 & 8 \\
\hline 9. & $\begin{array}{l}\text { Zalecenia monitoringu } \\
\text { Monitoring recommendations }\end{array}$ & $\mathrm{n}$ & $\mathrm{n}$ & $\mathrm{n}$ & $\mathrm{n}$ & $\begin{array}{l}\mathrm{t} \\
\text { (bez } \\
\text { propozycji } \\
\text { zakresu) }\end{array}$ & $\begin{array}{l}\mathrm{t} \\
\text { (z propozycją } \\
\text { zakresu } \\
\text { i częstotliwoś ci) }\end{array}$ \\
\hline 10. & $\begin{array}{l}\text { Wnioski dotyczace oddziaływania } \\
\text { inwestycji i ochrony gleb } \\
\text { Conclusions regarding the impact } \\
\text { of investment and soil protection }\end{array}$ & $\mathrm{n}$ & $\mathrm{n}$ & $\mathrm{n}$ & $\mathrm{n}$ & $\mathrm{n}$ & $\mathrm{t}$ \\
\hline 11. & $\begin{array}{l}\text { Gleby na mapach tematycznych } \\
\text { w raporcie ooś } \\
\text { Soil maps in the EIA report }\end{array}$ & $\mathrm{n}$ & $\mathrm{n}$ & $\mathrm{n}$ & $\mathrm{n}$ & $\mathrm{n}$ & $\mathrm{n}$ \\
\hline 12. & $\begin{array}{l}\text { OGÓLNA OCENA RAPORTU OOŚ } \\
\text { OVERALL ASSESSMENT EIA } \\
\text { REPORT }\end{array}$ & $\mathrm{N}$ & $\mathrm{N}$ & $\mathrm{N}$ & $\mathrm{N}$ & $\mathrm{N}$ & $\mathrm{P}$ \\
\hline
\end{tabular}

Objaśnienia: $\mathrm{B}$ - budowa nowego obiektu, $\mathrm{R}$ - rozbudowa istniejącego obiektu; $\mathrm{t}$ - tak, $\mathrm{n}$ - nie, gi - badania geologiczno-inżynierskie, $\mathrm{h}$ - badania hydrogeologiczne, ssg-w - badania stanu środowiska gruntowo-wodnego, w tym gleb, N - ocena negatywna, P - ocena pozytywna Legend: $\mathrm{B}$ - construction of a new facility, $\mathrm{R}$ - expansion of the existing facility; $\mathrm{t}$ - yes, $\mathrm{n}$ - no, gi - geological-engineering studies, $\mathrm{h}$ - hydrogeological studies, ssg-w - of the soil and water environment, including soil, $\mathrm{N}$ - negative rating, $\mathrm{P}$ - positive rating

i substancji ropopochodnych w glebach rejonu planowanej inwestycji i odniesiono je do wartości określonych w rozporządzeniu Ministra Środowiska z dnia 9 września 2002 r. w sprawie standardów jakości gleby oraz standardów jakości ziemi (Dz.U. 2002, nr 165, poz. 1359).

Dla potrzeb analizowanych raportów o oddziaływaniu na środowisko planowanych inwestycji nie przeprowadzono badań związanych $\mathrm{z}$ rozpoznaniem aktualnego stanu gleb, choć byłyby wskazane w związku z lokalizacją inwestycji w rejonach, które mogły być zanieczyszczone.

W większości opracowań nie uwzględniono również typów gleb (Z1, Z2, Z3, Z4, Z5) lub klas bonitacyjnych (Z1, Z2, Z3, Z5). W przypadku inwestycji $Z 4$, autorzy charakteryzując gleby odnieśli się wprawdzie do klas bonitacyjnych, ale podali jedynie, że w rejonie inwestycji występują, ,gleby o niskich klasach bonitacyjnych". W raportach nie odniesiono się również do rodzaju i gatunku gleby (za wyjątkiem Z6). Użytkowanie gleb zostało omówione w raportach ooś inwestycji Z2, Z4, Z5, Z6, przy czym w przypadku Z5 omówiono użytkowanie gleb w całej gminie, nie odnosząc się do terenu planowanej inwestycji.

Zgodnie $\mathrm{z}$ wymogami ustawy $\mathrm{z}$ dnia 3 października 2008 roku o udostępnianiu informacji o środowisku i jego ochronie, udziale społeczeństwa w ochronie środowiska oraz o ocenach oddziaływania na środowisko, bardzo ważnym elementem raportu o oddziaływaniu na środowisko jest analiza oddziaływania inwestycji na środowisko, w tym gleby. We wszystkich analizowanych raportach umieszczono rozdziały poświęcone temu zagadnieniu, ale wpływ inwestycji na gleby w trakcie jej realizacji i eksploatacji przeanalizowany został $\mathrm{z}$ różną dokładnością.

Najwięcej szczegółów i najdokładniejsze poruszenie kwestii oddziaływania inwestycji na gleby znaleźć można w raporcie o oddziaływaniu na środowisko inwestycji Z6. W ramach analizy oddziaływania na gleby na etapie budowy podkreślono, że planowana inwestycja będzie realizowana na terenie częściowo przekształconym, w związku ze składowaniem na nim w przeszłości popiołów z elektrociepłowni i, że maksymalnie wykorzystane zostaną elementy infrastruktury dawnego składowiska popiołów. Zwrócono uwagę na możliwość wystapienia wycieków olejów lub paliwa z maszyn pracujaccych w trakcie prowadzonych prac budowlanych, oddziaływanie na gleby zaplecza budowlanego, a także konieczność usunięcia i zabezpieczenia wierzchniej warstwy gleby (warstwy próchnicznej) do ponownego wykorzystania. Określono sposób wykorzystania warstwy próchnicznej, a także gleby i ziemi pochodzącej z wykopów. W analizie oddziaływania inwestycji na gleby na etapie eksploatacji zwrócono uwagę, że dużym zagrożeniem dla gleb mogą być ścieki powstające na terenie zakładu w sytuacji nieszczelności systemu kanalizacji, gdyż mogą one zawierać znaczne ilości metali ciężkich. Odniesiono się również do procesu kompostowania, w wyniku którego będzie występowała emisja pyłu do powietrza oraz emisja zanieczyszczeń mikrobiologicznych. Podkreślono jednak, że zasięg emisji zanieczyszczeń mikrobiologicznych nie przekracza zwykle $50 \mathrm{~m}$, co potwierdzają szczegółowo omówione w opracowaniu wyniki badań prowadzonych w tym zakresie przez Kuliga i Ossowską- 
Cypryk (1999). W całej analizie odnoszono się do wrażliwości gleb i warunków gruntowo-wodnych określonych dla terenu inwestycji w rozdziale poświęconym charakterystyce środowiska.

W przypadku pozostałych inwestycji analiza wpływu tych obiektów dotyczyła łącznie oddziaływania na środowisko gruntowo-wodne, w tym gleby. Omówione w nich zostały ogólnie zagrożenia wynikające z rozlania na powierzchni ziemi produktów ropopochodnych w trakcie prowadzonych prac budowlanych, powstawania ścieków zanieczyszczonych metalami ciężkimi i produktami ropopochodnymi. Nie nawiązano w nich do właściwości gleb rejonu inwestycji ani do warunków gruntowo-wodnych. Analizy mogłyby dotyczyć dowolnego terenu w dowolnym miejscu oraz dowolnej działalności, w wyniku której powstawać będą ścieki i może zaistnieć zagrożenie zanieczyszczenia gleby, ziemi i wód gruntowych substancjami ropopochodnymi i metalami ciężkimi.

Ogólne zalecenia, dotyczące działań mających na celu zminimalizowanie bądź wykluczenie negatywnego oddziaływania inwestycji na gleby, zostały zaproponowane $\mathrm{w}$ większości raportów ooś ( $\mathrm{z}$ wyjątkiem Z1 i Z5). Zaproponowano właściwe zaprojektowanie uszczelnienia kwater, odpowiednią konstrukcję i pojemność zbiornika na odcieki, zaprojektowanie odpowiednich pojemników i boksów do magazynowania poszczególnych rodzajów odpadów, zastosowanie siatki ochronnej w strefie rozładunku.

$\mathrm{W}$ raporcie ooś inwestycji Z5 jako działanie ochronne zaproponowano „okresowy monitoring środowiska glebowego wokół zakładu". Nie jest to właściwe ujęcie, gdyż żaden monitoring środowiska nie może zastapić działań zabezpieczających środowisko przed negatywnym oddziaływaniem inwestycji. Monitoring środowiska stanowi jedynie element systemu kontroli skuteczności zastosowanych działań ochronnych.

Stwierdzono, że określony w raportach zakres monitoringu nie wykracza poza wymogi zawarte $\mathrm{w}$ rozporządzeniu Środowiska z dnia 9 grudnia 2002 roku w sprawie zakresu, czasu, sposobu oraz warunków prowadzenia monitoringu składowiska odpadów. Nie przewidziano w nich zatem monitoringu emisji bioaerozoli ani mikrobiologicznych zanieczyszczeń gleb, choć jak wynika z badań Frączka (2010), środowisko glebowe w rejonie składowisk odpadów komunalnych powinno być stale monitorowane pod kątem mikrobiologicznych wskaźników sanitarnych.

Zwrócono uwage, że we wszystkich analizowanych raportach o oddziaływaniu na środowisko, warstwa próchniczna gleby jest traktowana jako cała gleba lub określana jako warstwa glebotwórcza. Takie podejście jest najprawdopodobniej spowodowane obowiązującą w prawodawstwie definicją gleby. Ustawa z dnia 27 kwietnia 2001 r. Prawo ochrony środowiska (t. jedn.: Dz.U. 2013, poz. 1232 z późn. $\mathrm{zm}$.) definiuje bowiem glebę jako górnq warstwe litosfery, złożonq z czesści mineralnych, materii organicznej, wody glebowej, powietrza glebowego i organizmów, obejmujaca wierzchnia warstwe gleby i podglebie.

Podsumowując, należy stwierdzić, że analizowane raporty o oddziaływaniu na środowiska obiektów gospodarki odpadami prezentują zróżnicowany poziom wykonania w zakresie charakterystyki gleb, określenia ich stanu oraz przedstawienia oddziaływania inwestycji na te gleby. Przeważają opracowania ocenione negatywnie, jako niezadowalające. Zakres raportów ooś jest formalnie zgodny z wymogami ustawy z dnia 3 października 2008 r. o udostępnianiu informacji o środowisku i jego ochronie, udziale społeczeństwa w ochronie środowiska. Jednak charakterystyka gleb i oddziaływanie na nie inwestycji w większości raportów są przedstawione bardzo pobieżnie i nie pozwalają na rzetelną ocenę wpływu inwestycji na gleby.

\section{Propozycje zakresu rozpoznania gleb dla potrzeb analizy oddziaływania obiektów gospodarki odpadami na ten element środowiska}

Zakres prac, niezbędnych do rzetelnej analizy oddziaływania obiektów gospodarki odpadami na gleby, powinien rozpoczynać się zebraniem jak najbardziej szczegółowych informacji dotyczących terenu inwestycji i jej sąsiedztwa w promieniu ok. $0,5-1 \mathrm{~km}$ od niego, w zależności od lokalnych warunków geomorfologicznych (tab. 2).

Jednym z najważniejszych elementów tego rozpoznania jest analiza wyników wszelkich archiwalnych badań gleb dostępnych w operatach do map klasyfikacyjnych lub wyników badań wykonywanych w ramach dokumentacji geologicznych, przeglądów ekologicznych i innych opracowań sozologicznych wykonanych dla analizowanego terenu, a także zebranie informacji o historii użytkowania terenu. W ramach opracowania charakterystyki gleb rejonu inwestycji wskazane jest również dokonanie przeglądu artykułów naukowych i ekspertyz omawiających badania gleb i środowiska gruntowo-wodnego w rejonie planowanej inwestycji lub terenach o podobnych walorach przyrodniczych i użytkowaniu. Należy uwzględnić informacje zawarte na różnego rodzaju mapach, począwszy od glebowych map klasyfikacyjnych, map glebowo-rolniczych, a także map topo- 
TABELA 2. Lista sprawdzająca zakres informacji niezbędnych do analizy oddziaływania obiektów gospodarki odpadami na gleby TABLE 2. Checklist of the scope of information required for the examination of effects of waste management facilities on soils

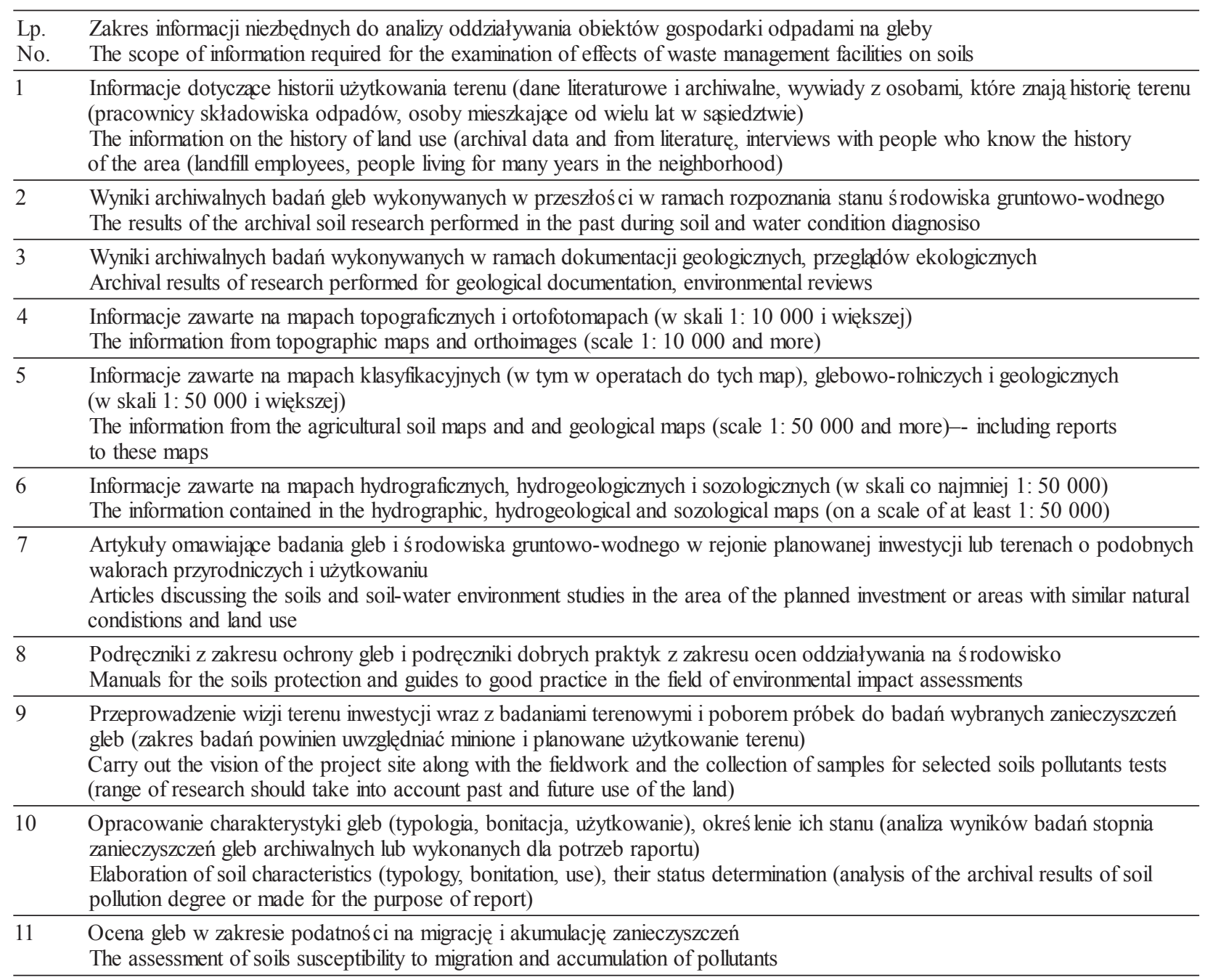

graficznych i ortofotomap, przez mapy geologiczne, hydrograficzne, hydrogeologiczne i sozologiczne.

Ważnym elementem analizy oddziaływania inwestycji na gleby jest przeprowadzenie wizji terenu inwestycji. W ramach prac terenowych konieczne jest zwrócenie uwagi na aktualne zagospodarowanie i użytkowanie terenu, a co za tym idzie użytkowania gleb. Pozwoli to na stwierdzenie, czy w przeszłości teren mógł zostać zanieczyszczony i ułatwi opis gleb z uwzględnieniem ich typów, rodzaju i gatunku, klas bonitacyjnych, użytkowania gleb, a także wrażliwości gleb i ich podatności na migrację i akumulację zanieczyszczeń.

Taka analiza materiałów archiwalnych w połączeniu z wizją terenu pozwolą na wskazanie miejsc poboru próbek i określenie zakresu niezbędnych badań laboratoryjnych, w celu określenia właściwości gleb oraz stopnia ich zanieczyszczenia, o ile takie rozpoznanie będzie wskazane. Analizy próbek glebowych można wykonywać w specjalistycznych laboratoriach, m.in. w instytucjach naukowych lub w stacjach chemiczno-rolniczych. Zakres badań powinien uwzględniać minione i planowane użytkowanie terenu. Ma to duże znaczenie zwłaszcza w przypadku inwestycji lokalizowanych na terenach, na których w przeszłości prowadzona był działalność mogąca zanieczyścić glebę i szeroko rozumiane środowisko gruntowo-wodne.

Analiza oddziaływania planowanej inwestycji na gleby powinna uwzględniać wszelkie aspekty, w tym wzajemne powiązania między takim komponentami środowiska, jak: gleby i środowisko-gruntowo wodne, gleby i powietrze atmosferyczne. Ważne jest zatem, by w analizie oddziaływania dla etapu budowy rozważyć, nie tylko możliwość bezpośredniego zanieczyszczenia gleby poprzez wycieki paliwa z maszyn budowlanych, ale też emisję spalin i związaną z tym możliwość akumulowania się w glebach takich 
zanieczyszczeń, jak rtęć i wielopierścieniowe węglowodory aromatyczne.

Analiza oddziaływania na gleby w eksploatacji obiektu powinna uwzględniać przede wszystkim emisje zanieczyszczeń do powietrza, w szczególności bioaerozoli oraz gospodarkę wodno-ściekową obiektu w zakresie emisji ścieków do środowiska gruntowo-wodnego i gleb. $Z$ tych emisji mogą bowiem pochodzić główne zanieczyszczenia gleb w sąsiedztwie obiektów gospodarki odpadami.

Ważnym elementem raportu o oddziaływaniu inwestycji na środowisko jest przedstawienie propozycji monitoringu środowiska w otoczeniu obiektu. Większość autorów, bez względu na możliwe zagrożenia środowiska, zaleca monitoring ograniczony do minimum, czyli do zapisów rozporządzenia Ministra Środowiska z dnia 9 grudnia 2002 roku w sprawie zakresu, czasu, sposobu oraz warunków prowadzenia monitoringu składowiska odpadów. Warto rozważyć jednak szerszy zakres monitoringu i jak zaleca Frączek (2010) uwzględnić badania gleb w zakresie obecności metali ciężkich i mikrobiologicznych wskaźników sanitarnych.

Gleby są elementem środowiska, który w wyniku funkcjonowania obiektów gospodarki odpadami może być narażony na zanieczyszczenia. Nie powinno się marginalizować tego problemu w raportach o oddziaływaniu na środowisko takich inwestycji.

\section{WNIOSKI}

1. Analizowane raporty o oddziaływaniu na środowisko obiektów gospodarki odpadami prezentują zróżnicowany poziom wykonania w zakresie analizy oddziaływania inwestycji na gleby. Przeważają opracowania ocenione negatywnie, jako niezadowalające.

2. Zakres analiz oddziaływania obiektów gospodarki odpadami na gleby nie obejmuje wszystkich aspektów wymaganych przez art. 66 ustawy ooś. Najczęściej pomijana lub bardzo ogólnikowa jest charakterystyka gleb, zarówno pod względem ich typologii, przydatności rolniczej sposobu użytkowania, jak również stopnia zanieczyszczenia. Opisane oddziaływania inwestycji na gleby są również bardzo ogólnikowe i teoretyczne, w większości przypadków mogą się odnosić do dowolnej inwestycji zlokalizowanej w dowolnym rejonie.

3. Konieczne jest zweryfikowanie sposobu podejścia do analizy oddziaływania obiektów gospodarki odpadami na powierzchnię ziemi, a w szczególności na gleby.

\section{REFERENCES}

Barabasz W., Chmiel M.J., Albińska D., Mazur M.A., 2007. Składowiska odpadów jako źródła bioaerozolu i mikroorganizmów szkodliwych dla zdrowia. Prace Instytutu Nafty i Gazu 145: 143-152.

Bojarska K., Bzowski Z., 2009. Monitoring środowiska w rejonie składowiska odpadów komunalnych w Zakopanem. Ochrona środowiska i zasobów naturalnych, 40: 632-642.

Frączek K., 2010. Sezonowe zmiany wskaźników stanu sanitarnego gleby na terenie oraz w rejonie składowiska odpadów komunalnych aglomeracji krakowskiej. Woda-ŚrodowiskoObszary wiejskie, t. 10, z. 2 (30): 49-60.

Gruszczyński S., 2006. Ocena i prognozowanie stanu gleb na potrzeby planów i programów, Inżynieria Środowiska, 11(1): 53-70.

Gurwin J., Janczarski P., 1998. Badania modelowe zanieczyszczenia substancjami ropopochodnymi na terenach lotnisk w Brzegu i w Szprotawie, Przegląd Geologiczny, 46(6): 509516.

Jędrczak A., Drab M., 1989. Zanieczyszczenie gleb i roślin w otoczeniu składowiska odpadów przemysłowych Szczecina. Archiwum Ochrony Środowiska, 3-4: 183-199.

Kabata-Pendias A., Pendias H., 1999. Biogeochemia pierwiastków śladowych. PWN, Warszawa: 400 pp.

Karmolińska-Słotkowska H., Domański S., 2009. Raport o oddziaływaniu na środowisko dla planowanej budowy Zakładu Zagospodarowania Odpadów w m. Bełżyce dla potrzeb Celowego Związku Gmin „PROEKOB” z siedzibą w Bełżycach, ul. Lubelska 3 (maszynopis).

Kaszubkiewicz J., Chodak T., Bogacz A., 1998. Morfologia i właściwości antropogenicznych profili glebowych z terenu lotniska w Brzegu Opolskim. Archiwum Ochrony Środowiska, 24(1): 93-109.

Kondras M., Czępińska-Kamińska S., Chodkowska A., Chrzanowska A., 2010. Ocena ekotoksykologiczna gleb w sąsiedztwie składowiska odpadów w Łubnej. Roczniki Gleboznawcze - Soil Science Annual, 61(4): 105-112.

Kulig A., Ossowska-Cypryk K., 1999. Problematyka badań mikrobiologicznych w ocenach oddziaływania na środowisko obiektów komunalnych - zagadnienia metodyczne. Problemy ocen środowiskowych, kwartalnik 1(4): 51-58.

Nałęcz T., Skalmowski A., Ferchmin M., Barszcz A., Kościński M., 2011. Raport o oddziaływaniu na środowisko przedsięwzięcia „Uruchomienie Zakładu Unieszkodliwiania Odpadów Ekolina" zlokalizowanego na działkach: 76, 77, 78, 79, 80, $81,82,83,84,85,86,87,88,89,90,91,92,95,99,100,103$, $106,117,119,120$ obręb 5-60-01 w gminie Zielonka (maszynopis).

Niedźwiecki E., Nowak A., Friedrich S., Michalcewicz W., Wojcieszczuk T., Meller W., 2008. Oddziaływanie wysypiska odpadów komunalnych w Sierakowie na właściwości chemiczne i mikrobiologiczne gleb. Roczniki Gleboznawcze - Soil Science Annual, 59(3/4): 215-225.

Przybulewska K., Nowak A., Głąbowska D., 2010. Zmiany w mikroflorze gleby wokół składowiska odpadów komunalnych w Łęczycy k. Stargardu Szczecińskiego. Woda Środ. Obsz. Wiej. 30(2): 159-166. 
Rozporządzenie Rady Ministrów z dnia 9 listopada 2010 r. w sprawie przedsięwzięć mogących znacząco oddziaływać na środowisko (Dz.U. 2010, nr 213, poz. 1397 z późn. zm.).

Rozporządzenie Ministra Środowiska z dnia 9 września 2002 r. w sprawie standardów jakości gleby oraz standardów jakości ziemi (Dz.U. 2002, nr 165, poz. 1359).

Rozporządzenie Ministra Środowiska z dnia 9 grudnia 2002 r. w sprawie zakresu, czasu, sposobu oraz warunków prowadzenia monitoringu składowisk odpadów (Dz.U. 2002, nr 220, poz. 1858).

Rydian G., 2010. Raport o oddziaływaniu przedsięwzięcia na środowisko Zakład Zagospodarowania Odpadów Jarocin (maszynopis).

Szymkowiak I., Witkowska J., Przybyła M., Sergiel E., 2008. Raport o oddziaływaniu na środowisko projektowanej budowy Zakładu Zagospodarowania Odpadów w miejscowości Kopaszyn Nowe, gm. Wagrowiec (maszynopis).

Szyszkowski P. (red.), 2000. Metody badania i rozpoznawania wpływu na środowisko gruntowo-wodne składowisk odpa- dów stałych. Poradnik. Ministerstwo Środowiska, Oficyna Wydawnicza EL-Press Warszawa: $218 \mathrm{~s}$.

Świercz A., 2005. Zawartość metali ciężkich w glebach rdzawych bielicowych w pobliżu wysypiska odpadów komunalnych Promnik (województwo świętokrzyskie). Roczniki Gleboznawcze - Soil Science Annual, 56(3/4): 106-111.

Ustawa $z$ dnia 3 października 2008 r. o udostępnianiu informacji o środowisku i jego ochronie, udziale społeczeństwa w ochronie środowiska oraz o ocenach oddziaływania na środowisko (tekst jedn.: Dz.U. 2013, poz. 1235 z późn. zm.).

Ustawa $z$ dnia $z$ dnia 27 kwietnia 2001 r. Prawo ochrony środowiska (tekst jedn.: Dz.U. 2013, poz. 1232 z późn. zm.).

Wojewódka D., 2009. Raport oddziaływania na środowisko przedsięwzięcia inwestycyjnego polegającego na budowie zakładu unieszkodliwiania i odzysku odpadów w gminie Skarbimierz (maszynopis).

Zgiet J.P., Szwaczko W., 2011. Raport o oddziaływaniu na środowisko przedsięwzięcia pn. „Budowa Zakładu Zagospodarowania Odpadów w Siemiatyczach” (maszynopis).

\title{
Analysis of soil condition in environmental impact assessment reports of selected waste management facilities in Poland
}

\begin{abstract}
Soil is among those elements of the natural environment which are frequently being exposed to pollution and degradation. Waste management facilities represent one of the most serious environmental threats, and landfill sites belong to the dominating pollution sources. Waste management facilities in Poland are counted among investments which are likely to significantly affect the environment. A majority of waste management facilities has been having EIA procedures carried out including a report on environmental impact. However, soil protection has mostly been marginalized in such reports. The aim of this work was to perform a qualitative examination of EIA reports for selected waste management facilities taking into special account soil condition analyses which constitute an inherent part of the reports. Furthermore, the work aimed at providing guidelines to design the scope of activities indispensable for a reliable analysis of impacts of waste management facilities on soils. The results of the examination indicate that the EIA reports analyzed vary in the accuracy level when assessing the impact of waste management facilities on soil conditions, and most of them were considered to be unsatisfactory in that regard.
\end{abstract}

Keywords: soil, environmental impact assessment, effect on soils 